\title{
Social competence and the need for approval and life satisfaction of women with excess body weight and women of normal weight- preliminary report
}

\author{
Joanna Miniszewska ${ }^{1} \mathrm{~A}, \mathrm{C}, \mathrm{D}, \mathrm{E}, \mathrm{F}$, Katherine Kogut ${ }^{2} \mathrm{~A}, \mathrm{~B}, \mathrm{C}, \mathrm{D}, \mathrm{F}$ \\ ${ }^{1}$ Institute of Psychology, Health Psychology Department, University of Lodz \\ ${ }^{2}$ The Specialist Hospital in Sanok, Autonomous Public Healthcare Centre
}

\begin{abstract}
The purpose of the present study is to examine the life satisfaction levels in two groups of women - with excess body weight and normal weight and the relationship between life satisfaction and the level of social competences The study involved 70 women (35 with excess body weight and 35 with normal weight). The Life Satisfaction Questionnaire, Social Competence Questionnaire and Social Approval Questionnaire were used in the study._The study revealed no significant differences in terms of overall life satisfaction among women with excess weight and normal weight and a number of other relationships between the variables (like the importance of the need for social approval for the assessment of life satisfaction in those who have excess body weight).
\end{abstract}

Keywords: life satisfaction, social competencies, the need for approval, excessive body weight

\section{Introduction}

Excessive weight and obesity have become the major problems of the modern world. According to Łuszczyńska [1] "... overweight and obesity are among the major biopsychological problems of mankind, resulting from complex psychological, biological and social mechanisms (p. 13)". The number of individuals suffering from the problem is constantly on the rise - The World Health Organization reports that the number of obese people worldwide has more than doubled since 1980. In 2008, the overweight accounted for some $35 \%$ of the overall adult population and the obese accounted for $12 \%$ of the population. In 2010, the number of overweight children under the age of 5 was estimated to be 40 million [2]. Numerous damages and disease risks related to excess body weight are well-known - it is enought to mention increased blood pressure, higher risk of diabetes and excessive burden put on the osteoarticular system [1].

It needs emphasizing that excessive body weight may have some psychosocial consequences [1,3-6]. Discrimination against obese people is becoming more widespread. Obese individuals are not only perceived as less attractive but they are rated more negatively [3,7,8-10]. As Chanduszko-Salska and Chodkiewicz emphasize [6], the relationship between excessive body weight and the social or psychological functioning of individuals is complex and multidimensional. Stress and the difficulties of dealing with it, as well as a low level of personal resources are factors that hugely contribute to the spread of obesity - people with excess body weight, unlike the people of normal weight, suffer from lower self-esteem and less effectiveness. Plus to that, they tend to deal with life's challenges through excessive eating. The psychological situation of the obese is also difficult - they struggle with specific problems associated with their weight, stigma, dissatisfaction with their own body, the necessity of the use of dietary restrictions, and they also regard themselves unable to control their impulses or habits [6,11]. Grzesiuk [12] emphasizes that obese people, regardless of their sex, are less likely to go out and meet their friends or build successful social relationships. Obese people often feel lonely, due to the reluctant attitudes of other people. This is also associated with the fear of experiencing further harassment or grievances. Bishop [13] reports that obese people are generally less popular, which translates into limited opportunities in their love life, tend to receive worse grades at school, earn lower salaries and they are often subject to negative assessement. Overweight individuals experience mood disorders (such as major depression or bipolar affective disorder) more often than people of normal weight, [1]. Numerous studies show that quality of life in the obese is reduced and obesity increases with decreasing satisfaction with various aspects of life [6, 14-20].

On the other hand, some obese people are described as cheerful, sociable, popular or successful [3]. Moreover, not all obese people perceive their weight as a problem. Being obese is then not synonymous with social isolation. There are also obese people achieving considerable suc- 
cess both in their professional and social life [21]. Zubrzycka [22] points out that an obese person often feels almost obliged to entertain others, as they erroneously think that slim individuals are accepted and liked as if by default, while overweight individuals have to gain favor. Obese individuals often conform to others, because they believes they have no right to make their own decisions or choices. They tend to traits of an excellent companion or a witty mocker and, what's more, become the life and soul of the party. Such a person hurts no one, he/she can be watchful and delicate. Carr and Friedman [8] have shown that obese people are as satisfied about their social relationships (both with partners or friends and co-workers) as thwhose individuals of normal weight A part of the reason might be that these relationships are voluntary and intentional, i.e. selected and developed in a conscious way, so as to ensure meeting their social and emotional needs. Interactions which do ensure that are simply rejected or only those that provide emotional warmth and support are chosen.

Due to various views on excessive weight, the authors decided to analyze the subjective assessment of the psychosocial functioning of both women of excess body weight and those of normal weight. The individuals' social context was considered because: a) one of the key determinants of life quality was the effectiveness of social functioning [23]; b) despite social ostracism, people with excess body weight appear be satisfied with their relationships with the surrounding world, largely to the same extent as those of normal weight [8,24]; c) people with excess body weight tend to adapt well to social requirements $[8,21,22]$.

The main aim of this study was to:

1. Compare the level of life satisfaction (in all aspects) among women of excess body weight and those of normal weight.

2. Determine the relationship between life satisfaction (explained variable) and the level of social competence and the need for social approval in women with excess body weight and in women with normal weight. The analyses also looked at the age, body weight and the BMI (body-mass index).

Based on the literature available, the following hypotheses were proposed:

1. Women with excess body weight declare less satisfaction with life, as compared to women of normal weight.

2. Women with excess body weight show a higher level of social competence and a stronger need for social approval, as compared to women of normal weight.

3. In both groups, the level of social competence positively correlates with life satisfaction. There is a negative correlation between the need for social approval and life satisfaction.

\section{Material}

The study group consisted of 70 women (35 with excess body weight and 35 of normal weight). The authors took two criteria into account, when selecting subjects. Firstly - the study consisted of people who have reached the age of 18, secondly - the weight-growth index was calculated (BMI $\geq 25$ in the women with excess body weight and BMI $\geq 18.5$ and $\leq 24.9$ in women of normal weight). The study of the subjects enrolled in the experimental group was carried out mainly at the SPA University Hospital in Ciechocinek. The average age of women from the group with excess body weight was $\mathrm{M}=48.22$ $(\mathrm{SD}=12.42)$, mean $\mathrm{BMI}=32.34(\mathrm{SD}=7.51)$. In the second group, the means are, respectively, $\mathrm{M}=46.57, \mathrm{SD}=12.62$ (age); $\mathrm{M}=21.43, \mathrm{SD}=1.47$ (BMI). Table. 1 shows the characteristics of the study groups.

Table 1. Profile of the studied groups

\begin{tabular}{|l|c|c|c|c|}
\hline \multirow{2}{*}{\multicolumn{1}{|c|}{$\mathrm{N}=70$}} & \multicolumn{2}{c|}{$\begin{array}{c}\text { BMI } \geq 25 \\
(\mathrm{~N}=35)\end{array}$} & \multicolumn{2}{c|}{$\begin{array}{c}\text { BMI } \leq 24,9 \\
(\mathrm{~N}=35)\end{array}$} \\
\cline { 2 - 6 } & $\mathrm{N}$ & $\%$ & $\mathrm{~N}$ & $\%$ \\
\hline Education: & 9 & 25.70 & 1 & 2.85 \\
\hline $\begin{array}{l}\text { Primary/Professional/ } \\
\text { Lower secondary }\end{array}$ & 19 & 54.23 & 12 & 34.28 \\
\hline Secondary & 7 & 20.00 & 22 & 62.85 \\
\hline Higher & 6 & 17.14 & 10 & 28.57 \\
\hline Cvil status: & 7 & 77.14 & 22 & 62.85 \\
\hline Singles & 2 & 5.71 & 3 & 8.57 \\
\hline Couples & & & & \\
\hline Divorced/Widowed & - & - & 100 & 100 \\
\hline BMI ranges: & 8 & 51.43 & - & - \\
\hline Normal weight & 7 & 20.00 & - & - \\
\hline Over weight & 3 & 8.57 & - & - \\
\hline Class I obesity & 7 & 20.00 & - & - \\
\hline Class II obesity &
\end{tabular}

\section{Methods}

The study used:

Life Satisfaction Questionnaire by Fahrenberg et al. FLZ (Fragebogen zur Lebenszufriedenheit) adapted by Chodkiewicz [25]. Overall, life satisfaction is understood an individual's assessment of their living conditions both in the present and the past, as well as the perceived future prospects [26]. It is a method of self-assessment, it consists of 70 items, making up 10 detailed scales that determine satisfaction with health, employment and occupation, financial situation, leisure, contacts with own children, oneself, friends, relatives and acquaintances, housing, marriage or partnership and sexuality. The tool makes it possible to calculate the overall life satisfaction by adding the raw scores of seven scales (the so-called overall scale). The tool's reliability and validity are satisfactory enough [25]. 
Social Competence Questionnaire (SCQ) by Matczak [27] measuring "social competence understood as complex abilities conditioning efficiency to cope with a particular type of social situations, acquired by a unit in the course of social training" $(2001$, p. 7). This tool consists of 90 items, out of which 60 are of a diagnostic (meaning related to social competences) and 30 are of non-diagnostic nature, which means that they are not taken into account when calculating results (they refer to unsocial skills, including manual and technical ones). Most diagnostic items refer to three factorial scales:

- I (competence that affects the effectiveness of behaviors in intimate situations);

- A (competence that affects the effectiveness of behaviors in situations that require assertiveness);

- ES (competence that affects the effectiveness of behaviors in situations of social exposure).

This tool has good psychometric properties [27].

Drwal and Wilczyńska's Social Approval Questionnaire [28] was used for measuring social approval, i.e. the desire of acceptance in relationships with other people, and the associated willingness to behave in a socially acceptable way. The questionnaire also makes it possible to define attitudes towards research, serving as a control scale that detects the tendency to present oneself in a too favorable or unfavorable light. In other words, the greater the need for social approval, the greater the probability the falsification of results. The questionnaire is characterized by high reliability and good accuracy [28].

The body mass index (BMI, Quetelet index) used for assessing body weight. The following formula is used for calculations: $\mathrm{BMI}=$ weight $(\mathrm{kg})$ : [height $\left.(\mathrm{m})^{2}\right]$. The BMI is the basis for determining the following ranges:

$<16.0$ - severe thinness; $16.0-16.99$ - moderate thinness; 17.0 - 18.5- underweight, 18.5 - 24.9 - normal weight; 25 - 29.9 - overweight; 30 - 39.9 - obesity; > 40 enormous obesity [3].

There are also three degrees according to which obesity should be classified. They, differ within the BMI range and the risk of the complications that may ensue class I - BMI> 30.0-34.9; class II - BMI> 35 to 39.9; class II - $\mathrm{BMI}>40$ [29].

The student's t test for independent samples was used for statistical analysis, which made it possible to determine the significance of differences between the mean values in the groups that were looked at. The Pearson's $r$ correlation coefficient was used for measuring the linear relationship between two variables and the stepwise multiple regression enabled determination of the total impact of a number of explanatory variables on the variable being explained. The Shapiro-Wilk test was used for verifying the distribution of results. Calculations were performed using STATISTICA software.
The study was approved by the Bioethics Committee of the University of Lodz (No. KBBN-UŁ/II/10/2013)

\section{Results}

\section{Life satisfaction level in the studied groups}

Table 2 displays the mean and standard deviation results obtained using the Life Satisfaction Questionnaire and the differences between women of excessive weight and those of normal weight. It turns out that the respondent women with excess body weight and those of normal weight differ only in respect to two life satisfaction dimensions: satisfaction with contacts with their children and satisfaction with their own health. In this case, women with excessive weight relatively often (this is statistically significant) rated their relationships with children as positive. At the same time, they considered their own health much worse. Other aspects of life satisfaction were assessed at a similar level. So, with the exception of the mentioned dimensions, no other differences in the assessment of life satisfaction were reported. Thus, the first hypothesis was not confirmed, women with excess body weight did not declare lower life satisfaction level, as compared to women of normal weight.

\section{Social competence and the need for social approval}

Table 3 shows the mean values and the standard deviation of the surveyed women in the Social Competence Questionnaire and the Social Approval Questionnaire. Differences between women of excess body weight and normal weight concerned only one variable - social approval. The results of women in the group characterized by excess body weight were significantly better, which may mean that, firstly, they have a much greater need for social approval, secondly, their results must be viewed with caution, as they could have resulted from a strong desire to be seen in a better light. Thus, the second hypothesis (Women with excess body weight show a higher level of social competence and a stronger need for social approval, unlike women of normal weight) was only partly confirmed.

\section{Psychological correlates of life satisfaction}

Another part of the analyses was to find correlates of both the overall life satisfaction and its various dimensions. Tables 4 and 5 show correlations between life satisfaction and social competence and the need for approval. In the case of women with excess body weight, the relationship between life satisfaction and the studied variables is relatively small - they concern the positive correlation between competence affecting the efficiency of behavior in intimate situations and the overall life satisfaction ( $r=0.37, p=028)$, satisfaction with one's financial condition $(r=0.45, p=006)$ and leisure satisfaction $(r=0.42 ; p=0.011)$. 
Table 2. Results of life satisfaction in the examined groups

\begin{tabular}{|c|c|c|c|c|c|c|c|}
\hline \multirow{2}{*}{ Life Satisfaction } & \multicolumn{2}{|c|}{$\mathrm{BMI} \geq 25 \mathrm{~N}=35$} & \multicolumn{2}{|c|}{$\mathrm{BMI} \leq 24,9 \mathrm{~N}=35$} & \multirow{2}{*}{ df } & \multirow{2}{*}{$\mathrm{t}$} & \multirow{2}{*}{$\mathrm{p}$} \\
\hline & $\mathrm{M}$ & SD & $\mathrm{M}$ & SD & & & \\
\hline Health & 31.85 & 7.30 & 34.97 & 5.51 & 68 & -2.01 & 0.04 \\
\hline Job and work & 30.31 & 8.44 & 32.60 & 6.88 & 68 & -1.25 & 0.21 \\
\hline Financial situation & 29.42 & 6.73 & 30.48 & 8.37 & 68 & -0.58 & 0.56 \\
\hline Leisure time & 33.42 & 6.45 & 32.31 & 8.19 & 68 & 0.63 & 0.52 \\
\hline Children & 35.48 & 13.95 & 22.05 & 19.90 & 68 & 3.26 & 0.001 \\
\hline Myself & 35.74 & 4.55 & 36.40 & 4.99 & 68 & -0.57 & 0.56 \\
\hline Friends/ acquaintance/Relatives & 36.51 & 5.12 & 34.82 & 5.40 & 68 & 1.33 & 0.18 \\
\hline Accommodation & 36.31 & 6.30 & 36.31 & 6.32 & 68 & 0.00 & 1.00 \\
\hline Marriage/Partnership & 30.57 & 16.07 & 34.20 & 15.58 & 68 & -0.95 & 0.34 \\
\hline Sex & 34.60 & 8.56 & 37.48 & 7.76 & 68 & -1.47 & 0.14 \\
\hline Total life satisfaction & 237.88 & 33.18 & 242.80 & 36.25 & 68 & -0.59 & 0.52 \\
\hline
\end{tabular}

Table 3. Results of social competence and social approval in the examined groups

\begin{tabular}{|c|c|c|c|c|c|c|c|}
\hline \multirow{2}{*}{$\begin{array}{l}\text { Social competence } \\
\text { and social approval }\end{array}$} & \multicolumn{2}{|c|}{$\mathrm{BMI} \geq 25 \mathrm{~N}=35$} & \multicolumn{2}{|c|}{$\mathrm{BMI} \leq 24,9 \mathrm{~N}=35$} & \multirow{2}{*}{$\mathrm{df}$} & \multirow{2}{*}{$\mathrm{t}$} & \multirow{2}{*}{$\mathrm{p}$} \\
\hline & M & SD & M & SD & & & \\
\hline Competence-intimate situations & 44.14 & 7.70 & 44.28 & 0.48 & 68 & -0.07 & 0.48 \\
\hline Competence- social exposure & 49.22 & 7.49 & 51.57 & 11.04 & 68 & -1.08 & 0.06 \\
\hline Competence- assertiveness & 47.82 & 7.78 & 47.68 & 9.29 & 68 & 0.06 & 0.94 \\
\hline Social competence-total & 172.60 & 23.85 & 175.57 & 32.51 & 68 & -0.43 & 0.66 \\
\hline Social approval & 17.05 & 4.19 & 13.97 & 5.04 & 68 & 2.01 & 0.04 \\
\hline
\end{tabular}

Table 4. Correlation coefficients between social competences, social approval and life satisfaction in the group of women with excess body weight

\begin{tabular}{|l|c|c|c|c|c|}
\hline & $\begin{array}{c}\text { Competence- } \\
\text { intimate situations }\end{array}$ & $\begin{array}{c}\text { Competence- } \\
\text { social exposure }\end{array}$ & $\begin{array}{c}\text { Competence- } \\
\text { assertiveness }\end{array}$ & $\begin{array}{c}\text { Social } \\
\text { competence-total }\end{array}$ & $\begin{array}{c}\text { Social } \\
\text { approval }\end{array}$ \\
\hline Health & 0.18 & 0.07 & -0.47 & 0.02 & $0.46^{* *}$ \\
\hline Job and work & 0.29 & 0.07 & 0.08 & 0.19 & -0.06 \\
\hline Financial situation & $0.45^{* *}$ & 0.19 & 0.27 & 0.31 & 0.16 \\
\hline Leisure time & $0.42^{*}$ & 0.08 & 0.05 & 0.21 & 0.21 \\
\hline Children & $-0,05$ & -0.27 & -0.11 & -0.18 & 0.29 \\
\hline Myself & 0.25 & 0.11 & -0.14 & 0.06 & 0.30 \\
\hline Friends/ acquaintances/Relatives & 0.31 & 0.07 & 0.23 & 0.26 & 0.23 \\
\hline Accommodation & 0.07 & -0.07 & -0.10 & -0.07 & $0.42^{* *}$ \\
\hline Marriage/ Partnership & 0.24 & -0.05 & -0.06 & 0.01 & 0.32 \\
\hline Sex & 0.21 & -0.11 & -0.09 & -0.03 & 0.22 \\
\hline Total life satisfaction & $0.37^{*}$ & 0.03 & 0.27 & 0.13 & $0.39^{*}$ \\
\hline
\end{tabular}

${ }^{*} \mathrm{p}<0.05 ;{ }^{* *} \mathrm{p}<0.01 ;{ }^{* * *} \mathrm{p}<0.001$

Table 5. Correlation coefficients between social competences, social approval and life satisfaction in the group of women with normal weight

\begin{tabular}{|l|c|c|c|c|}
\hline & $\begin{array}{c}\text { Competence- } \\
\text { intimate situations }\end{array}$ & $\begin{array}{c}\text { Competence- } \\
\text { social exposure }\end{array}$ & $\begin{array}{c}\text { Competence- } \\
\text { assertiveness }\end{array}$ & $\begin{array}{c}\text { Social } \\
\text { competence-total }\end{array}$ \\
approval
\end{tabular}

${ }^{*} \mathrm{p}<0.05 ;{ }^{* *} \mathrm{p}<0.01 ;{ }^{* * *} \mathrm{p}<0.001$ 
What is more, the greater the need for social approval in a certain group, the greater the declared satisfaction with their health $(r=0.46 ; p=0.005)$, housing $(r=0.42 ; p=$ $0.01)$ and their overall life satisfaction $(r=0.39 ; p=0.02)$.

In case of women of normal weight, there is a number of other dependencies, too. First of all, the overall life satisfaction correlates positively with all of the factors mentioned. Life satisfaction is all the greater the higher the level of all social skills (competence conditioning efficiency in close interpersonal relationships $r=0.68, p=0.001$; competence conditioning efficiency in social exposure situations: $r=0.61 ; p=0.001$; competence conditioning efficiency in situations requiring assertive behavior: $r=0.37 ; p=0.02)$ and the greater the need for social approval $(r=0.54 ; p=0.001)$. It is worth noting that their satisfaction with their own health is only correlated with their level of competence related to social exposure $(r=0.37 ; p=0.02)$, and their job satisfaction $(\mathrm{r}=0.40 ; \mathrm{p}=0.01)$ and their contacts with children $(r=-0.51 ; p=0.002)$ with the need for social approval. Satisfaction with relationships is only correlated with the level of social competence conditioning efficiency of behaviors in intimate situations $(\mathrm{r}=0.34 ; \mathrm{p}=0.04)$. The need for social approval in this group is not only related to relationship / marriage satisfaction - in other words, the greater the need for social approval, the better the assessment of one's own situation (except for health and relationship satisfaction).

In the light of the presented results, it can be stated that the third hypothesis (In both groups, the level of social competence is positively correlated with life satisfaction. The severity of the need for social approval is negatively correlated with life satisfaction) was also only partially confirmed.

\section{Life satisfaction and body weight, BMI and age}

As described in this paper, the authors also decided to look at variables such as body weight, BMI and age (Tab. 6). By analyzing the relationship between life satisfaction, weight and BMI in women of excessive weight, it can be concluded that job satisfaction levels increase along with an increase in these variables (respectively, $r=0.51 ; p=0.002$ and $r=0.50 ; p=0.001)$, and satisfaction with housing conditions decreases $(r=-0.36 ; p=0.03)$. On the other hand, job satisfaction $(r=0.34 ; p=0.04)$ and being satisfied by one's relations with their children $(r=0,38 ; p=0.21)$ increase with age. Relationships between the abovementioned variables in the second group are different: the higher the weight and the BMI the lower the health satisfaction (respectively, $r=-0.42, p=0.01$ and $r=-0.47 ; p=0.004$ ) and the leisure time satisfaction $(r=-0.48 ; p=0.003$ and $r=-0.42 \mathrm{p}=0.01$ ). The BMI itself if negatively correlated with one's satisfaction with their financial situation $(r=-0.34 ; p=0.05)$, sex life $(r=-0.37 ; p=0.02)$ and the overall assessment of life satisfaction ( $r=-0.42 p=0.01)$. With age, relationships with children tend to bring more satisfaction $(r=0.55 ; p=0.0001)$. Meanwhile, the satisfaction with financial status ( $r=-0.60 ; \mathrm{p}=0.0001)$, free time activities $(r=-0.53 ; p=0.001)$, self-assessment $(r=-0.35 ; p=0.03)$, housing $(r=-0.49 ; p=0.002)$, sex life $(r=-51 ; p=0.002)$ and the overall life satisfaction $(r=-0.58 ; p=0.0001)$ start decreasing.

Table 6 . Correlation coefficients between weight, BMI, age and life satisfaction in both groups

\begin{tabular}{|c|c|c|c|}
\hline Life satisfaction & Weight & BMI & Age \\
\hline \multicolumn{4}{|c|}{$\begin{array}{c}\text { Women with excess body weight } \\
\mathrm{N}=35\end{array}$} \\
\hline Health & -0.08 & -0.15 & -0.27 \\
\hline Job and work & $0,51^{* *}$ & $0,50^{* *}$ & $0.34^{*}$ \\
\hline $\begin{array}{l}\text { Financial } \\
\text { situation }\end{array}$ & 0.17 & 0.15 & 0.02 \\
\hline Leisure time & 0.29 & 0.17 & -0.01 \\
\hline Children & 0.23 & 0.21 & $0.38^{*}$ \\
\hline Myself & 0.01 & 0.05 & 0.13 \\
\hline $\begin{array}{l}\text { Friends/ } \\
\text { acquaintance/ } \\
\text { Relatives }\end{array}$ & 0.25 & 0.18 & -0.05 \\
\hline Accommodation & -0.25 & $-0.36^{*}$ & -0.25 \\
\hline $\begin{array}{l}\text { Marriage/ } \\
\text { Partnership }\end{array}$ & -0.09 & -0.15 & 0.03 \\
\hline Sex & -0.02 & -0.15 & -0.27 \\
\hline $\begin{array}{l}\text { Total life } \\
\text { satisfaction }\end{array}$ & -0.00 & -0.09 & -0.18 \\
\hline \multicolumn{4}{|c|}{$\begin{array}{l}\text { Women with normal weight } \\
\mathrm{N}=35\end{array}$} \\
\hline Health & $0.42^{*}$ & $-0.47^{* *}$ & -0.22 \\
\hline Job and work & -0.08 & -0.08 & -0.26 \\
\hline $\begin{array}{l}\text { Financial } \\
\text { situation }\end{array}$ & -0.27 & $-0.34^{*}$ & $-0.60^{* * *}$ \\
\hline Leisure time & $-0.48^{* *}$ & $-0.42^{*}$ & $-0.53^{* *}$ \\
\hline Children & 0.21 & 0.20 & $-0.55^{* * *}$ \\
\hline Myself & -0.18 & -0.11 & $-0.35^{*}$ \\
\hline $\begin{array}{l}\text { Friends/ } \\
\text { acquaintance/ } \\
\text { Relatives }\end{array}$ & -0.24 & -0.21 & -0.27 \\
\hline Accommodation & -0.16 & -0.29 & $-0.49 * *$ \\
\hline $\begin{array}{l}\text { Marriage/ } \\
\text { Partnership }\end{array}$ & -0.13 & -0.14 & -0.26 \\
\hline Sex & -0.25 & $-0.37^{*}$ & $-0.51^{* *}$ \\
\hline $\begin{array}{l}\text { Total life } \\
\text { satisfaction }\end{array}$ & $-0.38 *$ & $-0.42^{*}$ & $-0.58^{* * *}$ \\
\hline
\end{tabular}

${ }^{*} \mathrm{p}<0.05 ;{ }^{* *} \mathrm{p}<0.01 ;{ }^{* * *} \mathrm{p}<0.001$

\section{Predictors of life satisfaction}

The last stage of the analyses included an attempt to identify predictors of the overall life satisfaction for the studied groups (Table 7 and 8). Due to a small number of respondents, only the social skills factors and the variable of the need for social approval were included in the regression equation. It turned out that in case of women of excessive body weight, it is the need for social approval that affects the overall life satisfaction (the percentage of the explained variance is not high, 14\%). On the other hand, among the group of women of normal weight, both social competence and the need for social approval turned out to be predictors, explaining approx. $44 \%$ of the variability of results. In both cases, the relationships were positive. 
Table 7. Predictors of life satisfaction in women with excess body weight group

\begin{tabular}{|l|c|c|c|c|c|}
\hline Variables & Beta & $\mathrm{B}$ & Bd st. & $\mathrm{t}$ & $\mathrm{p}$ \\
\hline Social approval & 0.41 & 3.31 & 1.26 & 2.61 & 0.01 \\
\hline Constant value & & 138.19 & 46.08 & 2.99 & 0.001 \\
\hline $\begin{array}{l}\mathrm{R}=0.437 ; \mathrm{R} 2=0.19 ; \text { Adjusted. } \mathrm{R} 2=0.14 ; \mathrm{F}(2,32)=3.37 ; \mathrm{p}<, 03 ; \\
\text { Standard error of the Estimate: } 30.75\end{array}$ \\
\hline
\end{tabular}

Table 8. Predictors of life satisfaction in women with normal weight

\begin{tabular}{|l|c|c|c|c|c|}
\hline Variables & Beta & B & Bd st. & $\mathrm{t}$ & $\mathrm{p}$ \\
\hline Social competence & 0.45 & 0.13 & 0.15 & 3.31 & 0.001 \\
\hline Social approval & 0.36 & 2.64 & 0.99 & 2.65 & 0.02 \\
\hline Constant value & & 115.90 & 25.75 & 4.50 & 0.001 \\
\hline $\begin{array}{l}\text { R= 0.68; R2=0.,47; Adjusted R2 }=0.44 ; \mathrm{F}(2.32)=14.45 ; \mathrm{p}<, 001 ; ; \\
\text { Standard error of the Estimate: 72.08 }\end{array}$
\end{tabular}

\section{Discussion}

The research studies included in literature available prove overweight and obese people tend to assess their life quality as lower than the individuals of normal weight $[6,14-20]$. This is understandable, given the physical (like, for example, increased fatigue, mobility problems, comorbidities) and psychosocial (including low self-esteem, stigma, social isolation) problems experienced by individuals of excess body weight. The relationship between excessive weight and quality of life seems to be a twodirectional one - it was shown that reducing excess body weight usually leads to an improvement of the overall quality of life, mood and perception of one's body, as well as the difficulties of maintaining reduced body weight along with the yo-yo effect are associated with decreased quality of life, mood deterioration and increased stress levels [6]. In light of the above, the results of the study concern us - the declared level of life satisfaction of women with excess body weight and women of normal weight differed a little. There was only one statistically significant difference, when it comes to satisfaction with one's own health (women of excessive weight proved less satisfied with their health) and contacts with their own children (in this case, people with excess body weight presented higher levels of satisfaction). More interestingly, the results of the studies carried out (using the same tool to measure life satisfaction, a similar number of respondents and a similar average age) by Chanduszko-Salska and Chodkiewicz [6] showed that overweight and obese women were less satisfied with almost all areas of their own life (with leisure time being the only exception). This might be, at least partly, explained by the fact that women with excess body weight had a significantly higher score concerning their need for social approval. Apparently, displaying a greater need for social approval, these individuals yearned to be seen in a more favorable light. Why were the results in this study not similar [6]? Part of the reason might be the place where research data was obtained.. This very study was carried out at the Spa University Hospital in Ciechocinek, a place where focusing on the psychosocial functioning is not necessarily the most important thing. In turn, the study by Chanduszko-Salska and Chodkiewicz [6] was carried out before the programs involving psychologists helping individuals lose weight, for which the surveyed women volunteered (the program was implemented at the Municipal Center for Health Prevention in Lodz). Hence, it is possible that women volunteering to the program of psychological help were both more willing to admit to their problems and situation with their weight. They might have been more aware of these, too. The women presented in the analyses could be more focused on being viewed in a more favorable light or looking to prove that their weight does not have any impact over their lives. Importantly, the surveyed women only declared lower satisfaction with their own health they stayed in a hospital. Defense mechanisms protecting against negative assessment of their own life situation and the previously-mentioned strong need for approval shown by the people around them also might have played a role. The huge need for social acceptance seems to be understandable in the light of the reports previouslydisclosed in the literature [8, 21, 22, 30, 31] - overweight and obese people have to deal with a widespread stigma (which happens even in medical facilities) by adapting to social requirements, so as to meet their emotional needs.

When it comes to the relationship between life satisfaction and the variables that were looked at in the study, it appeared that women with excess body weight showed a positive correlation between the competence affecting the efficiency of behavior in intimate situations and the overall life satisfaction, satisfaction with financial situation and free time. However, the strength of these dependencies is moderate. The positive correlation between weight, BMI and job satisfaction yielded a rather surprising result - the higher one's weight was, the more job satisfaction they declared (this relationship is strong). On the other hand, there was a moderate negative correlation between one's BMI and sexual satisfaction, which is understandable. The BMI value and body weight are not correlated with the overall life satisfaction. Similar results, i.e. no correlation between BMI and the overall perception of quality of life, were obtained by GnacińskaSzymańska, Dardzińska, Majkowicz \& Małgorzewicz [19]. The presented study also showed that the older one was, the more satisfied they were with both their job and relations with children.

As far as women of normal weight are concerned, there are many more dependencies - there is a positive correlation between their life satisfaction and the studied variables - the higher one's level of social competence and 
the stronger the need for social approval, the more life satisfaction they had. The strongest correlations are: a) competence related to efficiency in intimate contacts and satisfaction with leisure time, contacts with friends, housing, sex life and the overall life satisfaction b) competence affecting efficiency in social exposure situations and satisfaction with oneself, contacts with friends, housing, sex life and the overall life satisfaction c) the general level of social competence and satisfaction with housing, sexual functioning and the overall life satisfaction, d) the need for social approval and satisfaction with children (negative relationship), contacts with friends, sex life and the overall life satisfaction. Here, it needs emphasizing that in the group including women with excess body weight, the overall social competence seemed to have virtually no bearing over their life satisfaction. And, as BMI in women with excess body weight does not seem to be associated with life satisfaction, in women of normal weight the life satisfaction levels decrease with age and higher BMI (sic!). In addition, the older the respondents were, the less satisfied they were with their financial status, leisure and sexual life and they start to appreciate their relations with children more (in the latter case, as in the women with excess body weight). Thus, the results of the women in both groups seem to suggest that those characterized by excess body weight deny the existence of most of the difficulties in their psychosocial and physical functioning and the higher their weight, the more denial they show.

Another radical difference between the two groups of women was found through the regression analysis. When women of excess body weight are concerned, it is the need for social approval that affects their life satisfaction as such. At the same time, in women of normal weight it was both social competence and the need for social approval. Thus, it might be suggested that the stronger the need for social approval, the higher the risk for respondents showing themselves in a better light.

In light of these results, the following reflections can be attempted - the location where the study is conducted exerts huge influence on assessing life satisfaction and its determinants, so the obtained results should not be taken as valid for the whole population. Individuals that seek psychological help (displaying higher awareness of these problems, probably due to their serious impact) tend to think differently than people with excess body weight who do not look for such help. The latter probably are likely to use other, perhaps more adaptive mechanisms that protect them from experiencing psychosocial problems.

The high need for social approval visible among the study group suggests that denial and avoidance attitude toward coping with stress can have huge influence over life satisfaction. In addition, the longer the overweight lasts, the person is more likely to develop adaptive skills and they may even become resistant to negative information concerning the obesity issue. In this case, their being either overweight or obese (and the whole package of related inconveniences) is compensated in other areas, thereby not lowering the perceived overall satisfaction [6,23]. Moreover, despite a strong need for social approval, possibly biasing the results, it becomes evident that body weight is associated with the sexual life of the overweight and obese women. It might be concluded that in people of excessive weight it is the perceived social approval they experience, rather than the body weight itself, that plays a great role. The latter reflection, not directly related to the purpose of the analysis, concerns the point of a return to using (rarely occurring) lie scales in studies, especially in on groups of people whose social functioning and perception are somehow more complicated - e.g. associated with stigma.

This very analysis has some limitations, including the very small and unrepresentative research group. Thus, this paper should be treated as a part of a pilot study and some larger group of people is essential in the future, which pertains to both those subject to treatment and those not undergoing any treatment (neither medical nor psychological).

\section{Conclusions}

1. There are only two aspects of life satisfaction in which women of excessive body weight differ from those of normal weight - they assess their contacts with children better, while they assess their health much worse.

2. Women of excessive body weight had significantly higher scores on the scale of social approval. This might be due to the fact that they display a greater need for approval and that they wanted to be seen in a more positive light.

3. In case of women with excess body weight there is a positive correlation between competence affecting the efficiency of behavior in intimate situations and the overall life satisfaction, satisfaction with financial situation and free time. What is more, the greater the need for social approval in the group, the greater the declared satisfaction with their own health, housing and overall life satisfaction. In case of women of normal weight, there are significantly more interdependencies.

4. In case of women of excessive weight, it was, the need for social approval that affected their overall life satisfaction, while among those of normal weight it was both social competence and the need for social approval.

\section{Conflict of interest}

The authors have declared no conflict of interest. 


\section{References:}

1. Łuszczyńska A. Nadwaga i otyłość. Interwencje psychologiczne. Warszaw; PWN: 2007.

2. World Health Organization http://www.who.int/mediacentre /factsheets/fs311/en/.

3. Ogińska-Bulik N. Psychologia nadmiernego jedzenia. Łódź; Wydawnictwo Uniwersytetu Łódzkiego: 2004.

4. Brytek-Matera A. Obraz własnego ciała u otyłych kobiet: przyczyny i stopień niezadowolenia, związek $\mathrm{z}$ obniżoną samooceną i strategiami radzenia sobie ze stresem. Psych. Pol. 2010; 44 (2): 267-275.

5. Zerr P. Surpoids et obésité de l'adulte : prise en charge médicale de premier recours. Le Collège de la Haute Autorité de Santé, Saint-Denis La Plaine: 2011.

6. Chanduszko-Salska J, Chodkiewicz J. Zadowolenie z życia a poczucie własnej skuteczności, wsparcie społeczne oraz stan zdrowia u kobiet z nadwagą i otyłością. Endokr, Otyłość i Zab Przem Mat. 2010; 6 (4), 171-178.

7. Głębocka A., Szarzyńska M.: Stereotypy dotyczące osób otyłych a jakość życia ludzi w starszym wieku. Gerontol. Pol.; 2005;14 (4):, 260-265

8. Carr D., Friedman M. Body Weight and the Quality of Interpersonal relationships. Soc Psychol Q. 2006;69,127-49

9. Granberg E. Now my 'old self' is thin. Stigma Exits after Weight Loss. Social Psychology Quarterly 2011; 74 (1): 29-52.

10. Schafer M., Ferrarol K. The Stigma of Obesity. Does Perceived Weight Discrimination Affect Identity and Physical Health? Soc Psych 2011; 74 (1): 76-97.

11. Friedman K.E., Reichmann S.K., Comstanzo P.R. Zelli A., Ashmore J., Musant G.: Weight stigmatization and ideological beliefs: relation to psychological functioning in obese adults. Obes. Res.2005; 13 (5): 907-916.

12. Grzesiuk K. Psychologiczne aspekty otyłości. W: Janowski K., Artymiak M. red.., Człowiek chory - aspekty biopsychospołecznej. Lublin; Centrum Edukacji i Pomocy Psychologicznej: 2009; s. 313-335.

13. Bishop G. D. Psychologia zdrowia. Wrocław; Wydawnictwo ASTRUM: 2010.

14. Kushner R..F., Foster G.D.: Obesity and Quality of Life. Nutrition, 2010, 16 (10): 947-952.

15. Kolotkin R.L., Crosby R.D., Williams G.R., Rhys W., Hartley G., Nicol S.: The relationship between health-related quality of life and weight loss. Obes. Res.,2001; 9 (9): 564-571.

16. Wadden T.A., Phelan, S.: Assessment of quality of life in obese individuals. Obes. Res. 2002; 10 Suppl 1: 50S-7S.

17. Williamson, D.A. i O'Neil, P.F. Obesity and Quality of Life. W: Bray G.A., Bouchard C. red. , Handbook of obesity. Etiology and Pathophysiology. New York; Marcel Dekker: 2004, p. 1005-1028.

18. Fontaine K.R., Barofsky J., Cheskin L.J. Predictors of quality of life for obese persons. J Nerv Ment Dis, 1997;185(2): 120-122.

19. Gnacińska-Szymańska, M., Dardzińska, J. A., Majkowicz, M. i
Małgorzewicz, S.:Ocena jakości życia osób z nadmierna masą ciała za pomocą formularza WHOQOL-BREF. . Endokr., Otyłość i Zab Przem Mat. 2012; 8 (4): 136-142.

20. Sola M., Gajewska E., Manikowski, W. Wpływ otyłości na jakość życia związaną ze stanem zdrowia wśród dziewcząt i chłopców. Now. Lek. 2012; 81(4): 321-329.

21. Radoszewska J. Problem otyłości w psychologii klinicznej. Nowiny Psychologiczne 2003; 3: 23-31.

22. Zubrzycka E. Apetyt na zdrowie. Mity na temat nadwagi. Gdańsk; Gdańskie Wydawnictwo Psychologiczn :2007

23. Doliński D. Wpływ społeczny a jakość życia. Psychologia Jakości Życia 2002; 1: 35-52.

24. Carr D., Friedman M.:"Is Obesity Stigmatizing? Body Weight, Perceived Discrimination, and Psychological Well-Being in the United States." J Health Socl Behav 2005; 46: 244-59.

25. Chodkiewicz, J.: Adaptacja polska Kwestionariusza Zadowolenia z Życia FLZ. Studia Psychologiczne 2009; 47 (3): 5-21.

26. Fahrenberg J., Myrtek M. Schumacher, J., Brähler E. Fragebogen zur Lebenszufriedenheit. Göttingen; Hogrefe-Verlag: 2000.

27. Matczak A. Kwestionariusz Kompetencji Społecznych. Podręcznik. Warszawa; Pracownia Testów Psychologicznych Polskiego Towarzystwa Psychologicznego: 2001.

28. Drwal R. Ł., Wilczyńska J. T.: Opracowanie Kwestionariusza Aprobaty Społecznej. Przegląd Psychologiczny, 1980; 23 (3): 569-583.

29. Tatoń J., Czech A., Bernas M. Otyłość zespół metaboliczny. Warszawa; Wydawnictwo Lekarskie PZWL: 2007.

30. Puh, R., Heuer C.: The Stigma of Obesity: A Review and Update. Obes. 2009; 17 (5): 941-964.

31. Puhl R., Heuer C.: Obesity Stigma: Important Considerations for Public Health. Am. J. Public Health 2010;100 (6): 1019-1028.

32. Bąk-Sosnowska M., Zahorska-Markiewicz B., Mandal E. Trzcieniecka-Green A.: Poziom lęku oraz poczucie kontroli u kobiet decydujących się na rozpoczęcie kuracji odchudzającej. Psychiatr Pol, 2006; 40 (1): 99-107.

\section{Correspondence address}

Joanna Miniszewska

Health Psychology Department, Institute of Psychology, University of Lodz, 91-433 Lodz, Poland, ul. Smugowa 10/12

tel.608348080

e-mail:jminisz@poczta.onet.pl

Otrzymano: 08.05.2016

Zrecenzowano: 22.06.2016

Przyjęto do druku: 25.06.2016 